\title{
BIOTITICKÁ PLAGIOKLASOVÁ RULA Z KOUTŮ NAD DESNOU A REJHOTIC (VRBENSKÁ SKUPINA V ZÓNĚ ČERVENOHORSKÉHO SEDLA): NOVÉ MINERALOGICKÉ ÚDAJE
}

\author{
A biotite plagioclase gneiss from Kouty nad Desnou and Rejhotice (the Vrbno Group in the \\ Červenohorské sedlo Zone): new mineralogical data
}

\author{
Jiří Zimák \\ Katedra geologie PřF UP, tř. 17. listopadu 12, 77146 Olomouc; e-mail:jiri.zimak@upol.cz
}

(14-24 Bělá pod Pradědem)

Key words: Silesicum, Vrbno Group, plagioklase gneiss, mica schist, chlorite, biotite, staurolite, tourmaline

\begin{abstract}
The paper deals with metamorphic rocks of the Vrbno Group in the Červenohorské sedlo Zone near the Kouty nad Desnou village (north-eastern part of the Bohemian Massif). The studied rocks are named simply as biotite plagioclase gneiss in geological maps. Research has shown that most of the rocks in the area correspond to the graphite-bearing staurolite-biotite plagioclase gneiss. This gneiss merges into mica schist with the same mineral association but with a higher content of biotite. Plagioclase is a major and sometimes even dominant constituent of the rocks. Its composition varies from An ${ }_{39}$ to $A n_{84}$. Accessory minerals include ilmenite, apatite-(CaF), less often zircon, tourmaline (dravite), garnet (almandine), pyrite, and chalcopyrite. In the mentioned rocks, thin graphite-bearing chlorite plagioclase gneiss intercalations were found. Plagioclase has an extremely high basicity $\left(A n_{88-91}\right)$. It is obvious from the chemical and mineral composition of the studied rocks that their protolith had to be rich in iron, aluminum and calcium. Clay rocks can be assumed as protolith. The origin of clay sediments or clay residue was possibly linked to the weathering of basic volcanism products.
\end{abstract}

Úvod

V zóně Červenohorského sedla tvoří bezprostřední nadloží drakovských kvarcitů (báze vrbenské skupiny) grafitické fylity, svory nebo ruly (viz např. Cháb a Opletal 1984). Jde o horniny zajímavé přítomností bazického plagioklasu, jenž je jejich podstatnou složkou (již Bederke 1935 a Fabian 1936), a patrně jen zcela lokálním výskytem minerálů řady pumpellyitu (Kováčik et al. 2010). V této zprávě jsou mineralogicky zhodnoceny grafitické horniny svorového nebo rulového vzhledu vystupující na $z$. až sz. svahu Hřbetů a v údolí Divoké Desné (v. od Koutů nad Desnou) v moravské části zóny Červenohorského sedla, v území, které je podle geologické mapy (Opletal et al. 1997) tvořeno biotitickou plagioklasovou rulou.

\section{Vzorky a metody}

Studované horninové vzorky byly odebrány z výchozů v zářezech asfaltové lesní cesty směřující od silnice Kouty nad Desnou - Červenohorské sedlo do prostoru Hřbetů (vzorky 1 až 10 ), $\mathrm{z}$ větších fragmentů v deluviu u lesní cesty, po níž vede zeleně značená turistická trasa z údolí Divoké Desné k rozcestí „Pod Hřbety“ (vzorky 11 a 12) a z výchozů v údolí Divoké Desné u silnice vedoucí $\mathrm{z}$ Koutů nad Desnou k Přečerpávací vodní elektrárně Dlouhé Stráně (obr. 1, vzorky 13 a 14). GPS-souřadnice vzorků jsou v tabulce 1 . Vzorky 1 až 12 byly odebrány na k. ú. Kouty nad Desnou, vzorky 13 a 14 na k. ú. Rejhotice (tab. 2).

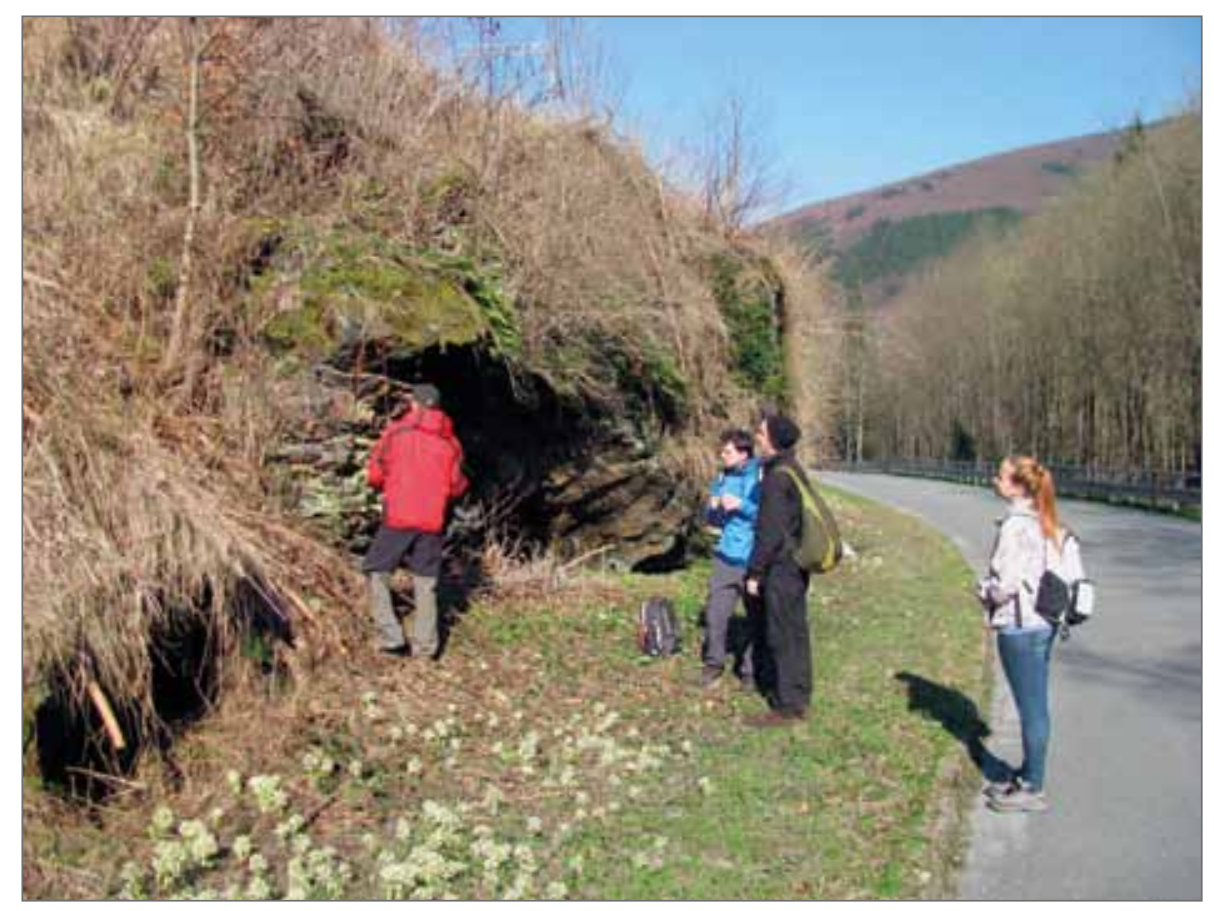

Obr. 1: Stauroliticko-biotitická plagioklasová rula v zářezu silnice v údolí Divoké Desné. Fig. 1: Staurolite-biotite plagioclase gneiss in the road cut in the Divoká Desná Valley. 
Tab. 1: GPS koordináty studovaných vzorků (stanoveno pomocí https://mapy.cz).

Tab. 1: GPS co-ordinates of studied samples (localized by https://mapy.cz).

\begin{tabular}{|c|c|c|}
\hline č. vzorku/GPS koordináty & $\mathrm{N}$ & $\mathrm{E}$ \\
\hline 1 & $50^{\circ} 6^{\prime} 21,6^{\prime \prime}$ & $17^{\circ} 9^{\prime} 12,8^{\prime \prime}$ \\
\hline $2=3$ & $50^{\circ} 6^{\prime} 19,1^{\prime \prime}$ & $17^{\circ} 9^{\prime} 13,4^{\prime \prime}$ \\
\hline 4 & $50^{\circ} 6^{\prime} 16,4^{\prime \prime}$ & $17^{\circ} 9^{\prime} 10,5^{\prime \prime}$ \\
\hline $5=6$ & $50^{\circ} 6^{\prime} 13,6^{\prime \prime}$ & $17^{\circ} 9^{‘} 8,0^{\prime \prime}$ \\
\hline 7 & $50^{\circ} 6^{\prime} 9,4^{\prime \prime}$ & $17^{\circ} 9^{\prime} 1,1^{\prime \prime}$ \\
\hline 8 & $50^{\circ} 6^{\circ} 4,9^{\prime \prime}$ & $17^{\circ} 9^{‘} 3,0^{\prime \prime}$ \\
\hline 9 & $50^{\circ} 6^{\prime} 8,9^{\prime \prime}$ & $17^{\circ} 9^{‘} 5,8^{\prime \prime}$ \\
\hline 10 & $50^{\circ} 6^{\prime} 11,8^{\prime \prime}$ & $17^{\circ} 9^{\prime} 15,2^{\prime \prime}$ \\
\hline $11=12$ & $50^{\circ} 6^{\prime} 13,8^{\prime \prime}$ & $17^{\circ} 9^{\prime} 17,9^{\prime \prime}$ \\
\hline 13 & $50^{\circ} 6^{\prime} 5,3^{\prime \prime}$ & $17^{\circ} 8$ ' $31,2^{\prime \prime}$ \\
\hline 14 & $50^{\circ} 6^{\circ} 1,2^{\prime \prime}$ & $17^{\circ} 8^{\prime} 37,7^{\prime \prime}$ \\
\hline
\end{tabular}

Údaje o chemismu 14 horninových vzorků byly získány pomocí XRF analyzátoru DELTA-PREMIUM v laboratořích firmy URGA, s.r.o. se sídlem v Olomouci (podrobný popis metodiky uvádí Zimák et al. 2016). Základem pro mineralogicko-petrografické hodnocení vybraných horninových vzorků bylo studium leštěných výbrusů $\mathrm{v}$ procházejícím i odraženém světle za použití standardního polarizačního mikroskopu. Chemismus vybraných minerálủ byl sledován metodou WDX pomocí elektronového mikroanalyzátoru Cameca SX100 (analytik P. Gadas, PřF MU Brno). Podmínky, za nichž byly provedeny WDX analýzy, může na požádání sdělit autor tohoto článku. Výsledky reprezentativních WDX analýz fylosilikátů (biotit, muskovit, chlorit), staurolitu, granátu a turmalínu jsou uvedeny v tabulce 2 a 3 . Hodnoty apfu byly vypočteny standardním způsobem na bázi 11 atomů $\mathrm{O}$ (slídy), 14 atomů $\mathrm{O}$ (chlority), 12 atomů $\mathrm{O}$ (granát) a 24,5 atomu $O$ (turmalín); v prrípadě staurolitu byl zvolen préepočet na 46 atomů $O$ (Feenstra et al. 2003). Železo je ve výsledcích všech WDX analýz uváděno sumárně jako $\mathrm{FeO}$. V př́ípadě granátu byl poměr mezi $\mathrm{Fe}^{2+} \mathrm{a} \mathrm{Fe}^{3+}$ kalku- lován na $\mathrm{R}^{2+}=3$, v obou analyzovaných bodech je železo při tomto přepočtu př́tomno jen jako $\mathrm{Fe}^{2+}$ (i tak je suma $\mathrm{R}^{2+}$ jen 2,98). Údaje o chemismu ostatních minerálů jsou pouze stručně komentovány $\mathrm{v}$ textu.

\section{Výsledky}

Ve studovaném souboru vzorků byly rozlišeny tři typy hornin, $\mathrm{v}$ následujícím textu označované jako chloritická plagioklasová rula (dále jen Ch-Pl-rula), stauroliticko-biotitická plagioklasová rula (St-Bt-Pl-rula) a stauroliticko-biotitický plagioklasový svor (St-Bt-Pl-svor). Všech tři typy hornin jsou grafitické (často silně), jejich společným znakem je proto šedočerná až černá barva. Vždy mají výraznou plošně paralelní texturu.

$\mathrm{Z}$ uvedených typů hornin je ve sledovaném území nejméně rozšířena Ch-Pl-rula. Je zastoupena pouze vzorky 3 a 11, pocházejícími z úseku, $\mathrm{z}$ něhož byla Kováčikem et al. (2010) popsána bytownitová rula s pumpellyitem (biotitická, ne chloritická). Makroskopická determinace minerálů je prakticky nemožná - lze rozlišit jen drobně šupinkovitý fylosilikát, zřejmá je přítomnost grafitu, v některých partiích jsou zřetelná drobná očka živce. Hornina je drobnozrnná, má lepidogranoblastickou strukturu. Její dominantní složkou je bazický plagioklas $\left(\mathrm{An}_{88-91}\right.$, WDX), tvořící více než $50 \%$ objemu horniny. Plagioklas je př́tomen v podobě drobných zrn i přes $1 \mathrm{~mm}$ velkých xenomorfně omezených poikiloblastů uzavírajících zrna křemene a další součástky základní tkáně, $\mathrm{z}$ nichž je nejnápadnější grafit. Plagioklasové porfyroblasty se často shlukují do drobných čočkovitých útvarů nebo i neprůběžných pásků, $v$ nichž bývají provázeny hlavně křemenem. Množství křemene v hornině je $15 \mathrm{až} 20 \mathrm{obj} . \%$. Ve vedlejším až podstatném množství je $v$ Ch-Pl-rule přítomen chlorit, vytvářející $\mathrm{v}$ hornině i samostatné pásky složené ze šupinek o velikosti do $0,1 \mathrm{~mm}$. Jde o chamosit $\mathrm{s}$ jen mírnou převahou $\mathrm{Fe}$ nad $\mathrm{Mg}$ ( $\mathrm{tab} .3$ ), v Melkově klasifikaci o thuringit, př́ípadně o chlorit při rozhraní thuringit/ripidolit (viz obr. 2), Podíl grafitu na modál-

Tab. 2: Celkový chemismus hornin (XRF analýzy, celkové železo uvedeno jako $\mathrm{Fe}_{2} \mathrm{O}_{3}$ ).

Tab. 2: Bulk chemistry of rocks (XRF analysis, total iron is presented as $\mathrm{Fe}_{2} \mathrm{O}_{3}$ ).

\begin{tabular}{|c|c|c|c|c|c|c|c|c|c|c|c|c|c|c|}
\hline hornina & Ch-F & -rula & St-Bt- & 1-rula & & St-Bt-Pt & vor a h & rnina nc & přechoo & ze St-F & -Pl-svor & u do St-B & t-Pl-rul & \\
\hline vzorek & 3 & 11 & 13 & 14 & 1 & 2 & 4 & 5 & 6 & 7 & 8 & 9 & 10 & 12 \\
\hline $\mathrm{SiO}_{2}(\mathrm{hm} . \%)$ & 61,06 & 48,34 & 41,26 & 36,06 & 53,18 & 45,38 & 38,61 & 44,79 & 37,19 & 44,05 & 41,07 & 52,60 & 50,20 & 42,07 \\
\hline $\mathrm{TiO}_{2}(\mathrm{hm} . \%)$ & 0,60 & 0,96 & 1,10 & 1,55 & 1,08 & 1,30 & 1,50 & 0,97 & 1,31 & 1,06 & 1,29 & 1,00 & 1,03 & 1,00 \\
\hline $\mathrm{Al}_{2} \mathrm{O}_{3}(\mathrm{hm} . \%)$ & 10,74 & 16,33 & 18,05 & 22,19 & 19,30 & 17,89 & 21,87 & 19,40 & 23,35 & 19,00 & 22,94 & 15,56 & 19,05 & 16,47 \\
\hline $\mathrm{Fe}_{2} \mathrm{O}_{3}(\mathrm{hm} . \%)$ & 6,30 & 9,27 & 7,82 & 7,99 & 6,17 & 7,73 & 7,88 & 9,39 & 6,41 & 7,38 & 8,62 & 8,41 & 7,36 & 9,33 \\
\hline $\mathrm{Cr}_{2} \mathrm{O}_{3}(\mathrm{hm} . \%)$ & $<0,01$ & $<0,01$ & $<0,01$ & 0,01 & $<0,01$ & 0,02 & 0,02 & $<0,01$ & 0,01 & $<0,01$ & 0,01 & $<0,01$ & $<0,01$ & $<0,01$ \\
\hline $\mathrm{CaO}$ (hm. \%) & 3,83 & 5,79 & 6,08 & 9,32 & 0,91 & 4,54 & 5,01 & 1,24 & 5,10 & 1,99 & 2,20 & 3,59 & 2,65 & 5,61 \\
\hline $\mathrm{MnO}(\mathrm{hm} . \%)$ & 0,04 & 0,09 & 0,06 & 0,05 & 0,03 & 0,07 & 0,09 & 0,05 & 0,06 & 0,04 & 0,07 & 0,07 & 0,06 & 0,09 \\
\hline $\mathrm{K}_{2} \mathrm{O}(\mathrm{hm} . \%)$ & 0,22 & $<0,20$ & 2,72 & 1,22 & 5,44 & 2,25 & 2,91 & 3,71 & 2,65 & 3,45 & 4,11 & 2,33 & 3,02 & 2,03 \\
\hline $\mathrm{P}_{2} \mathrm{O}_{5}(\mathrm{hm} . \%)$ & 0,14 & $<0,05$ & 0,22 & 0,25 & 0,07 & 0,07 & 0,19 & 0,23 & 0,46 & 0,21 & 0,08 & 0,10 & $<0,05$ & $<0,05$ \\
\hline S (hm. \%) & 0,48 & 0,11 & 0,41 & 0,18 & 0,31 & $<0,05$ & 0,13 & $<0,05$ & $<0,05$ & 0,13 & $<0,05$ & $<0,05$ & 0,42 & $<0,05$ \\
\hline $\mathrm{Cu}(\mathrm{ppm})$ & 31 & $<10$ & $<10$ & 33 & 29 & $<10$ & 27 & $<10$ & $<10$ & 25 & $<10$ & $<10$ & 30 & $<10$ \\
\hline $\mathrm{Zn}(\mathrm{ppm})$ & 45 & 67 & 142 & 175 & 44 & 102 & 148 & 167 & 99 & 73 & 167 & 90 & 100 & 87 \\
\hline $\mathrm{Pb}(\mathrm{ppm})$ & 13 & 21 & 29 & 34 & 20 & 24 & 52 & 14 & 39 & 17 & 30 & 28 & 27 & 25 \\
\hline $\mathrm{Rb}(\mathrm{ppm})$ & 35 & 27 & 154 & 129 & 209 & 169 & 134 & 208 & 141 & 235 & 227 & 144 & 171 & 133 \\
\hline $\mathrm{Sr}(\mathrm{ppm})$ & 167 & 251 & 370 & 505 & 150 & 318 & 352 & 97 & 365 & 266 & 213 & 234 & 204 & 270 \\
\hline $\mathrm{Zr}(\mathrm{ppm})$ & 102 & 154 & 205 & 282 & 189 & 210 & 248 & 163 & 217 & 183 & 216 & 188 & 184 & 176 \\
\hline
\end{tabular}


Tab. 3: Reprezentativní WDX analýzy fylosilikátů.

Tab. 3: Representative WDX analyses of phyllosilicates.

\begin{tabular}{|c|c|c|c|c|c|c|c|c|c|c|c|}
\hline & \multicolumn{4}{|c|}{ chlorit } & \multicolumn{5}{|c|}{ biotit } & \multicolumn{2}{|c|}{ muskovit } \\
\hline vzorek & 11 & 11 & 14 & 2 & 13 & 14 & 2 & 9 & 9 & 1 & 9 \\
\hline $\mathrm{SiO}_{2}(\mathrm{hm} . \%)$ & 24,51 & 24,07 & 23,07 & 23,83 & 35,10 & 33,47 & 35,08 & 34,75 & 34,77 & 46,9 & 45,94 \\
\hline $\mathrm{TiO}_{2}(\mathrm{hm} . \%)$ & 0,07 & 0,08 & 0,10 & 0,07 & 1,60 & 1,44 & 1,50 & 1,66 & 1,48 & 0,19 & 0,27 \\
\hline $\mathrm{Al}_{2} \mathrm{O}_{3}(\mathrm{hm} . \%)$ & 22,07 & 23,11 & 22,39 & 23,45 & 19,31 & 19,34 & 19,8 & 19,26 & 19,64 & 35,80 & 35,08 \\
\hline $\mathrm{Cr}_{2} \mathrm{O}_{3}(\mathrm{hm} . \%)$ & 0,12 & 0,08 & 0,09 & 0,04 & 0,04 & 0,06 & 0,04 & 0,05 & 0,06 & 0,03 & 0,04 \\
\hline $\mathrm{V}_{2} \mathrm{O}_{3}(\mathrm{hm} . \%)$ & 0,09 & 0,10 & 0,05 & 0,06 & 0,07 & 0,12 & 0,11 & 0,10 & 0,09 & 0,04 & 0,04 \\
\hline $\mathrm{BaO}$ (hm. \%) & 0 & 0 & 0 & 0 & 0,06 & 0,15 & 0,12 & 0,12 & 0,09 & 0,07 & 0,20 \\
\hline $\mathrm{CaO}$ (hm. \%) & 0 & 0,04 & 0 & 0,09 & 0,02 & 0,03 & 0,01 & 0,03 & 0,01 & 0,02 & 0,03 \\
\hline $\mathrm{FeO}$ (hm. \%) & 25,09 & 26,07 & 28,69 & 25,82 & 19,26 & 21,37 & 20,08 & 20,86 & 20,89 & 1,17 & 1,20 \\
\hline $\mathrm{MgO}$ (hm. \%) & 12,88 & 12,14 & 10,42 & 11,40 & 8,67 & 6,60 & 8,13 & 7,54 & 7,64 & 0,64 & 0,57 \\
\hline $\mathrm{MnO}$ (hm. \%) & 0,22 & 0,27 & 0,22 & 0,15 & 0,13 & 0,13 & 0,13 & 0,05 & 0,07 & 0,01 & 0 \\
\hline $\mathrm{NiO}$ (hm. \%) & 0 & 0 & 0,05 & 0,03 & 0,03 & 0,03 & 0,01 & 0,01 & 0 & 0,02 & 0,03 \\
\hline $\mathrm{SrO}(\mathrm{hm} . \%)$ & 0 & 0 & 0 & 0 & 0 & 0,02 & 0 & 0 & 0 & 0 & 0 \\
\hline $\mathrm{ZnO}(\mathrm{hm} . \%)$ & 0,05 & 0 & 0,05 & 0 & 0 & 0 & 0,04 & 0 & 0,03 & 0,01 & 0,01 \\
\hline $\mathrm{K}_{2} \mathrm{O}(\mathrm{hm} . \%)$ & 0,02 & 0,02 & 0,01 & 0,13 & 9,21 & 9,23 & 9,02 & 9,10 & 9,05 & 9,36 & 9,88 \\
\hline $\mathrm{Na}_{2} \mathrm{O}(\mathrm{hm} . \%)$ & 0,01 & 0 & 0 & 0,02 & 0,31 & 0,10 & 0,21 & 0,21 & 0,20 & 0,76 & 0,75 \\
\hline $\mathrm{F}(\mathrm{hm} . \%)$ & 0,03 & 0 & 0 & 0 & 0,22 & 0,22 & 0,30 & 0,25 & 0,26 & 0,14 & 0,11 \\
\hline $\mathrm{Cl}$ (hm. \%) & 0 & 0 & 0 & 0,01 & 0 & 0,02 & 0 & 0,01 & 0 & 0,01 & 0 \\
\hline $\mathrm{O}=\mathrm{F}(\mathrm{hm} . \%)$ & $-0,01$ & 0 & 0 & 0 & $-0,09$ & $-0,09$ & $-0,13$ & $-0,11$ & $-0,11$ & $-0,06$ & $-0,05$ \\
\hline $\mathrm{O}=\mathrm{Cl}(\mathrm{hm} . \%)$ & 0 & 0 & 0 & 0 & 0 & 0 & 0 & 0 & 0 & 0 & 0 \\
\hline suma (hm. \%) & 85,15 & 85,98 & 85,14 & 85,10 & 93,94 & 92,23 & 94,45 & 93,89 & 94,17 & 95,11 & 94,10 \\
\hline $\mathrm{Si}^{4+}$ & 2,66 & 2,60 & 2,57 & 2,60 & 2,71 & 2,67 & 2,70 & 2,70 & 2,69 & 3,10 & 3,09 \\
\hline $\mathrm{Ti}^{4+}$ & 0,01 & 0,01 & 0,01 & 0,01 & 0,09 & 0,09 & 0,09 & 0,10 & 0,09 & 0,01 & 0,01 \\
\hline $\mathrm{Al}^{3+}$ & 2,83 & 2,94 & 2,94 & 3,02 & 1,76 & 1,82 & 1,79 & 1,77 & 1,79 & 2,79 & 2,78 \\
\hline $\mathrm{Cr}^{3+}$ & 0,01 & 0,01 & 0,01 & 0 & 0 & 0 & 0 & 0 & 0 & 0 & 0 \\
\hline $\mathrm{V}^{3+}$ & 0,01 & 0,01 & 0 & 0,01 & 0 & 0,01 & 0,01 & 0,01 & 0,01 & 0 & 0 \\
\hline $\mathrm{Ba}^{2+}$ & 0 & 0 & 0 & 0 & 0 & 0,01 & 0 & 0 & 0 & 0 & 0,01 \\
\hline $\mathrm{Ca}^{2+}$ & 0 & 0,01 & 0 & 0,01 & 0 & 0 & 0 & 0 & 0 & 0 & 0 \\
\hline $\mathrm{Fe}^{2+}$ & 2,28 & 2,36 & 2,67 & 2,36 & 1,24 & 1,43 & 1,29 & 1,36 & 1,35 & 0,07 & 0,07 \\
\hline $\mathrm{Mg}^{2+}$ & 2,09 & 1,96 & 1,73 & 1,86 & 1,00 & 0,79 & 0,93 & 0,87 & 0,88 & 0,06 & 0,06 \\
\hline $\mathrm{Mn}^{2+}$ & 0,02 & 0,03 & 0,02 & 0,01 & 0,01 & 0,01 & 0,01 & 0 & 0,01 & 0 & 0 \\
\hline $\mathrm{K}^{+}$ & 0 & 0 & 0 & 0,02 & 0,91 & 0,94 & 0,88 & 0,90 & 0,89 & 0,79 & 0,85 \\
\hline $\mathrm{Na}^{+}$ & 0 & 0 & 0 & 0 & 0,05 & 0,02 & 0,03 & 0,03 & 0,03 & 0,10 & 0,10 \\
\hline $\mathrm{F}^{-}$ & 0,01 & 0 & 0 & 0 & 0,05 & 0,06 & 0,07 & 0,06 & 0,06 & 0,03 & 0,02 \\
\hline $\mathrm{O}^{2-}$ & 13,99 & 14,00 & 14,00 & 14,00 & 10,95 & 10,94 & 10,93 & 10,94 & 10,94 & 10,97 & 10,98 \\
\hline
\end{tabular}

ním složení Ch-Pl-ruly lze odhadnout na několik obj. \% (značná koncentrace grafitu místy znesnadňuje studium horniny v procházejícím světle). V akcesorickém množství byl zjištěn biotit (silně chloritizovaný), muskovit (ve formě sericitu v alterovaném plagioklasu), částečně leukoxenizovaný ilmenit, apatit-(CaF), zirkon, minerál skupiny $\mathrm{TiO}_{2}$, magnetit a pyrit.

V St-Bt-Pl-rule lze již makroskopicky rozlišit hnědočerné až černé lupínky biotitu o velikosti max. $2 \mathrm{~mm}$ a relativně hojné tmavě hnědé porfyroblasty staurolitu velké až $3 \mathrm{~mm}$, nápadné zejména na navětralých foliačních plochách. V hornině se střídají hrubozrnnější granoblastické křemen-živcové pásky či šmouhy s jen malým podílem biotitu a staurolitu s jemnozrnnějšími partiemi s lepidogranoblastickou až granolepidoblastickou strukturou, tvořenými shodnou minerální asociací, avšak s výrazně vyšším obsahem biotitu a staurolitu na úkor obou tektosilikátů. Zvyšováním podílu biotitu v uvedené minerální asociaci přechází St-Bt-Pl-rula do St-Bt-Pl-svoru, který má v typických př́ipadech granolepidoblastickou strukturu, bývá drobnozrnný nebo stř̌edně zrnitý. Jasně definovatelná hranice mezi oběma typy hornin neexistuje, většina vzorků odebraných ve sledovaném území má charakter St-Bt-Pl-svoru nebo St-Bt-Pl-svoru přecházejícího do St-Bt-Pl-ruly (tab. 2). Vzhledem ke značné podobnosti obou hornin (obdobný celkový chemismus, shodná minerální asociace) jsou v následujících odstavcích popsány společně, na př́ípadné rozdíly je upozorněno.

Světlé minerály jsou v St-Bt-Pl-rule a St-Bt-Pl-svoru zastoupeny pouze plagioklasem a křemenem, v St-Bt-Pl-rule je plagioklas vždy dominantní, v St-Bt-Pl-svoru zpravidla plagioklas převažuje nad křemenem. Zrna plagioklasu jsou xenomorfní o velikosti až $2 \mathrm{~mm}$, jejich okraje jsou zpravidla laločnaté. Mají povahu poikiloblastů, uzavírajících všechny minerály základní tkáně, hlavně však křemen a grafitickou substanci, uspořádanou někdy do detailně provrásněných tenkých pásků. Často se grafitická substance koncentruje $\mathrm{v}$ jádrech plagioklasů, která bývají obrůstána víceméně čirým plagioklasem, v XPL s náznaky polysyntetického lamelování. Zcela obdobné porfyroblasty plagioklasu popisují Fojt a Gregerová (1999) $\mathrm{Z}$ „černých grafitových břidlic“ $\mathrm{z}$ vrtu J-1, situovaného 


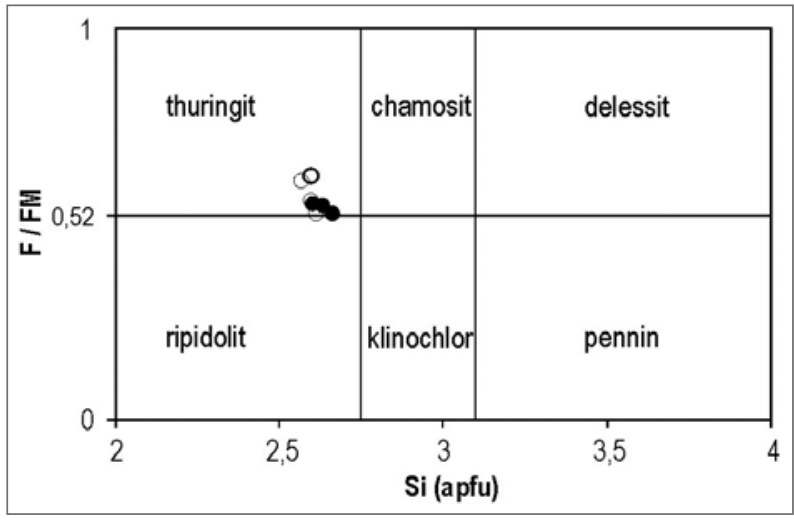

Obr. 2: Klasifikace chloritů z chloritické plagioklasové ruly (plné kroužky) a stauroliticko-biotitické plagioklasové ruly až svoru (prázdné kroužky) v diagramu podle Melky (1965).

Fig. 2: The classification of chlorites from chlorite plagioclase gneiss (full circles) and staurolite-biotite plagioclase gneiss to schist (open circles) in the diagram after Melka (1965).

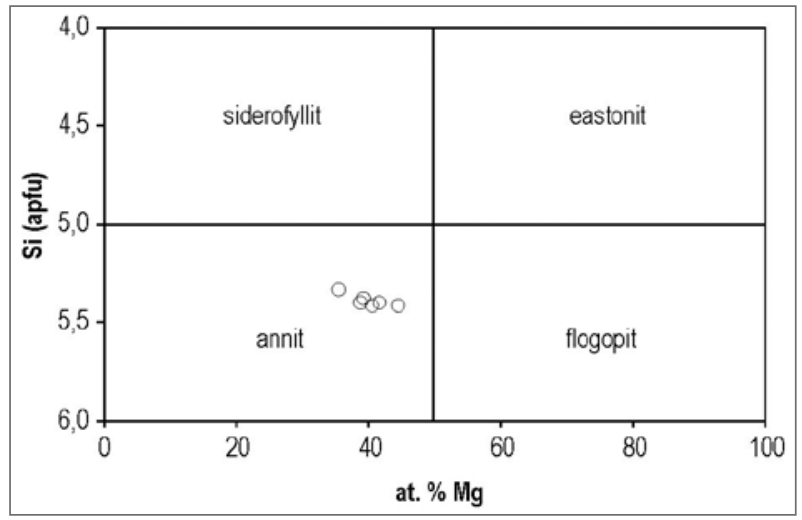

Obr. 3: Klasifikace biotitu ze stauroliticko-biotitické plagioklasové ruly až svoru v diagramu siderofyllit - eastonit - annit - flogopit.

Fig. 3: The classification of biotite from staurolite-biotite plagioclase gneiss to schist in the diagram siderophyllite - eastonite - annite - phlogopite.

Tab. 4: Reprezentativní WDX analýzy staurolitu, turmalínu a granátu.

Tab. 4: Representative WDX analyses of staurolite, tourmaline and garnet.

\begin{tabular}{|c|c|c|c|c|c|c|c|c|c|c|c|}
\hline \multirow[b]{2}{*}{ vzorek } & \multicolumn{7}{|c|}{ staurolit } & \multicolumn{2}{|c|}{ turmalín } & \multicolumn{2}{|c|}{ granát } \\
\hline & 1 & 2 & 2 & 5 & 9 & 9 & 13 & 9 & 9 & 2 & 2 \\
\hline $\mathrm{SiO}_{2}(\mathrm{hm} . \%)$ & 27,53 & 26,91 & 27,56 & 26,54 & 27,28 & 26,95 & 27,10 & 35,14 & 36,08 & 36,52 & 36,44 \\
\hline $\mathrm{TiO}_{2}(\mathrm{hm} . \%)$ & 0,43 & 0,52 & 0,50 & 0,40 & 0,56 & 0,42 & 0,25 & 1,85 & 0,93 & 0,03 & 0,01 \\
\hline $\mathrm{P}_{2} \mathrm{O}_{5}(\mathrm{hm} . \%)$ & nest. & 0,01 & 0,03 & nest. & 0,04 & 0 & nest. & 0 & 0,01 & 0 & 0 \\
\hline $\mathrm{Al}_{2} \mathrm{O}_{3}(\mathrm{hm} . \%)$ & 53,64 & 53,15 & 53,11 & 52,25 & 53,75 & 53,80 & 52,24 & 31,82 & 32,11 & 20,88 & 20,78 \\
\hline $\mathrm{Cr}_{2} \mathrm{O}_{3}(\mathrm{hm} . \%)$ & 0,04 & 0,12 & 0,08 & 0,04 & 0,02 & 0,04 & 0 & 0,06 & 0,10 & 0,01 & 0,06 \\
\hline $\mathrm{Sc}_{2} \mathrm{O}_{3}(\mathrm{hm} . \%)$ & nest. & 0 & 0,01 & nest. & 0 & 0 & nest. & nest. & nest. & 0,01 & 0 \\
\hline $\mathrm{V}_{2} \mathrm{O}_{3}(\mathrm{hm} . \%)$ & 0,04 & 0,02 & 0,10 & 0 & 0,06 & 0,02 & 0,02 & 0,10 & 0,06 & 0 & 0 \\
\hline $\mathrm{BaO}$ (hm. \%) & 0,01 & nest. & nest. & 0 & nest. & nest. & 0,02 & nest. & nest. & nest. & nest. \\
\hline $\mathrm{CaO}$ (hm. \%) & 0 & 0,03 & 0 & 0,03 & 0 & 0,01 & 0,01 & 0,59 & 0,67 & 3,01 & 2,71 \\
\hline $\mathrm{FeO}$ (hm. \%) & 13,84 & 14,07 & 14,28 & 12,68 & 14,21 & 14,34 & 13,63 & 8,31 & 7,36 & 30,97 & 31,17 \\
\hline $\mathrm{MgO}$ (hm. \%) & 1,35 & 1,29 & 1,37 & 0,73 & 1,35 & 1,33 & 1,25 & 5,20 & 6,08 & 1,88 & 1,56 \\
\hline $\mathrm{MnO}(\mathrm{hm} . \%)$ & 0,24 & 0,31 & 0,29 & 0,26 & 0,39 & 0,38 & 0,34 & 0 & 0,01 & 5,22 & 5,65 \\
\hline $\mathrm{NiO}$ (hm. \%) & 0,01 & 0,01 & 0 & 0 & 0 & 0,01 & 0,01 & nest. & nest. & nest. & nest. \\
\hline $\mathrm{ZnO}(\mathrm{hm} . \%)$ & 0,14 & 0,19 & 0,06 & 0,62 & 0,06 & 0,05 & 0,23 & 0,01 & 0 & 0 & 0,05 \\
\hline $\mathrm{K}_{2} \mathrm{O}(\mathrm{hm} . \%)$ & 0,01 & 0,02 & 0 & 0 & 0 & 0,01 & 0,01 & 0,01 & 0 & 0 & 0,01 \\
\hline $\mathrm{Na}_{2} \mathrm{O}(\mathrm{hm} . \%)$ & 0,02 & 0 & 0,04 & 0,05 & 0,02 & 0,04 & 0,02 & 1,74 & 1,75 & 0 & 0,02 \\
\hline F (hm. \%) & 0,06 & 0,06 & 0,06 & 0,04 & 0,04 & 0,07 & 0,06 & 0,37 & 0,19 & 0 & 0 \\
\hline $\mathrm{Cl}$ (hm. \%) & 0 & 0 & 0 & 0 & 0,01 & 0 & 0 & 0 & 0 & 0 & 0 \\
\hline $\mathrm{O}=\mathrm{F}(\mathrm{hm} . \%)$ & $-0,03$ & $-0,03$ & $-0,03$ & $-0,02$ & $-0,02$ & $-0,03$ & $-0,03$ & $-0,16$ & $-0,08$ & 0 & 0 \\
\hline $\mathrm{O}=\mathrm{Cl}(\mathrm{hm} . \%)$ & 0 & 0 & 0 & 0 & 0 & 0 & 0 & 0 & 0 & 0 & 0 \\
\hline suma (hm. \%) & 97,33 & 96,68 & 97,46 & 93,62 & 97,77 & 97,44 & 95,16 & 85,04 & 85,27 & 98,53 & 98,46 \\
\hline $\mathrm{Si}^{4+}$ & 7,69 & 7,60 & 7,71 & 7,70 & 7,61 & 7,55 & 7,75 & 5,85 & 5,95 & 2,99 & 3,00 \\
\hline $\mathrm{Ti}^{4+}$ & 0,09 & 0,11 & 0,11 & 0,09 & 0,12 & 0,09 & 0,05 & 0,23 & 0,12 & 0 & 0 \\
\hline $\mathrm{P}^{5+}$ & nest. & 0 & 0,01 & nest. & 0,01 & 0 & nest. & 0 & 0 & 0 & 0 \\
\hline $\mathrm{Al}^{3+}$ & 17,66 & 17,68 & 17,51 & 17,86 & 17,66 & 17,76 & 17,61 & 6,24 & 6,24 & 2,02 & 2,01 \\
\hline $\mathrm{Cr}^{3+}$ & 0,01 & 0,03 & 0,02 & 0,01 & 0 & 0,01 & 0 & 0,01 & 0,01 & 0 & 0 \\
\hline $\mathrm{V}^{3+}$ & 0,01 & 0,01 & 0,02 & 0 & 0,01 & 0 & 0,01 & 0,01 & 0,01 & 0 & 0 \\
\hline $\mathrm{Ca}^{2+}$ & 0 & 0,01 & 0 & 0,01 & 0 & 0 & 0 & 0,11 & 0,12 & 0,26 & 0,24 \\
\hline $\mathrm{Fe}^{2+}$ & 3,23 & 3,32 & 3,34 & 3,08 & 3,31 & 3,36 & 3,26 & 1,16 & 1,02 & 2,12 & 2,15 \\
\hline $\mathrm{Mg}^{2+}$ & 0,56 & 0,54 & 0,57 & 0,32 & 0,56 & 0,56 & 0,53 & 1,29 & 1,50 & 0,23 & 0,19 \\
\hline $\mathrm{Mn}^{2+}$ & 0,06 & 0,07 & 0,07 & 0,06 & 0,09 & 0,09 & 0,08 & 0 & 0 & 0,36 & 0,39 \\
\hline $\mathrm{Zn}^{2+}$ & 0,03 & 0,04 & 0,01 & 0,13 & 0,01 & 0,01 & 0,05 & 0 & 0 & 0 & 0 \\
\hline $\mathrm{K}^{+}$ & 0 & 0,01 & 0 & 0 & 0 & 0 & 0 & 0 & 0 & 0 & 0 \\
\hline $\mathrm{Na}^{+}$ & 0,01 & 0 & 0,02 & 0,03 & 0,01 & 0,02 & 0,01 & 0,56 & 0,56 & 0 & 0 \\
\hline $\mathrm{F}^{-}$ & 0,05 & 0,05 & 0,05 & 0,04 & 0,04 & 0,06 & 0,05 & 0,19 & 0,10 & 0 & 0 \\
\hline $\mathrm{O}^{2-}$ & 45,95 & 45,95 & 45,95 & 45,96 & 45,96 & 45,94 & 45,95 & 24,31 & 24,40 & 12,00 & 12,00 \\
\hline
\end{tabular}



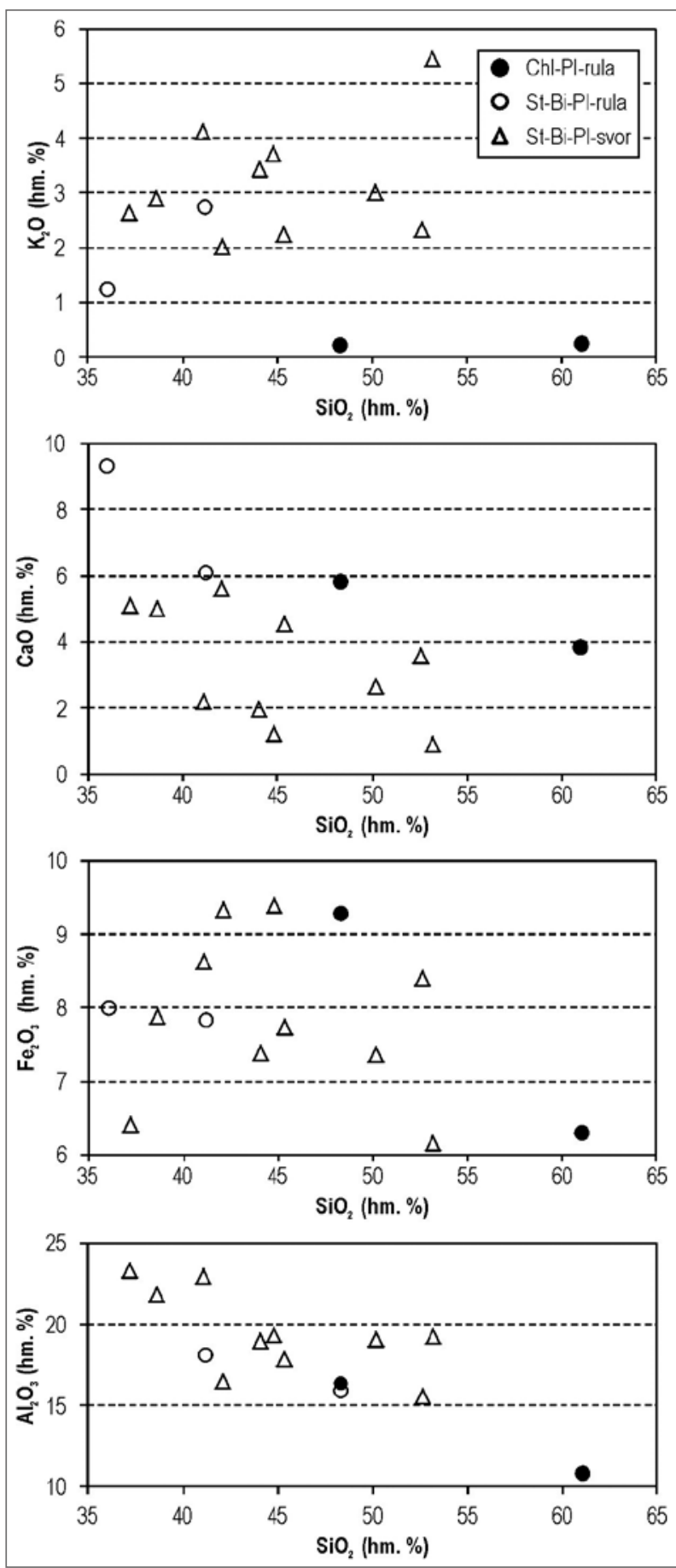

Obr. 4: Harkerův diagram pro studované horniny.

Fig. 4: Harker diagram of studied rocks.

$\mathrm{v}$ prostoru, $\mathrm{v}$ němž byly odebírány vzorky St-Bt-Pl-ruly a St-Bt-Pl-svoru. Bazicita plagioklasu kolísá v širokém intervalu $\mathrm{An}_{39-84}$ (WDX), v zrnech plagioklasu bývají př́tomny nepravidelně omezené partie lišící se bazicitou, mnohá zrna se však jak jeví jako chemicky víceméně homogenní, výrazná chemická zonálnost nebyla zjišš̌na ani $v$ jediném př́padě.

Křemen je běžnou součástí základné tkáně horniny, v níž tvoří xenomorfní zrna o velikosti do $0,3 \mathrm{~mm}$, $\mathrm{v}$ křemen-živcových páscích v St-Bt-Pl-svoru i o něco větší. Biotit byl ve výbrusech z St-Bt-Pl-ruly a St-Bt-Pl-svoru zastižen v podobě drobných šupinek (do $0,3 \mathrm{~mm}$ ) s výrazným pleochroismem (světle žlutá $\mathrm{x}$ hnědá až červenohnědá). Složení biotitu je uvedeno $v$ tabulce 3 (vzorky 2, 9, 13 a 14), odpovídá annitu (viz obr. 3). Biotit je místy chloritizován. V partiích s biotitem bývají př́ítomny i šupiny „příčného“ chloritu. Jeho složení odpovídá chamositu (tab. 3, vzorky 2 a 14). Množství staurolitu ve St-Bt-Pl-rule a St-Bt-Pl-svoru je velmi variabilní, zpravidla se koncentruje v partiích s vysokým podílem biotitu, $v$ nichž tvoří porfyroblasty (převážně xenoblasty). Nutno poznamenat, že Budil et al. (1999) ze St-Bt-Pl-ruly z téže oblasti uvádí dvě generace staurolitu. Výsledky WDX analýz staurolitu jsou obsaženy v tabulce 4 (vzorky 1, 2, 5,9 a 13). Staurolit obsahuje hojné uzavřeniny opakního pigmentu, tvořeného grafitem a ilmenitem. $\mathrm{V}$ základní tkáni horniny je př́tomen ilmenit $\mathrm{v}$ podobě nedokonale vyvinutých tabulek až kostrovitých individuí. V ilmenitu ze všech tř́ rozlišených typů hornin byla vedle $\mathrm{Fe}$ a $\mathrm{Ti}$ vždy stanovena podstatná př́měs Mn v množství 1,04 až $1,97 \mathrm{hm}$. \% MnO (to odpovídá 2 až $4 \mathrm{~mol}$. \% pyrofanitové složky). $\mathrm{V}$ analyzovaných bodech bylo dále zjišsěno (v hm. \%, uvedena maxima): $0,03 \mathrm{SiO}_{2}, 0,09 \mathrm{Nb}_{2} \mathrm{O}_{3}, 0,04$ $\mathrm{Ta}_{2} \mathrm{O}_{5}, 0,06 \mathrm{Al}_{2} \mathrm{O}_{3}, 0,03 \mathrm{Cr}_{2} \mathrm{O}_{3}, 0,04 \mathrm{Sc}_{2} \mathrm{O}_{3}, 0,06 \mathrm{~V}_{2} \mathrm{O}_{3}, 0,10$ $\mathrm{CaO}, 0,17 \mathrm{MgO}, 0,03 \mathrm{SnO}$ a $0,04 \mathrm{ZnO}$. Ilmenit bývá slabě postižen leukoxenizací. $\mathrm{V}$ produktech této přeměny byl vedle „nestechiometrických fází "obsahujících hlavně Ti a Fe, místy také $\mathrm{Ca}$ a $\mathrm{Si}$, nalezen minerál skupiny $\mathrm{TiO}_{2}$ (podle morfologie snad rutil). Pouze jako akcesorie byl v některých vzorcích St-Bt-Pl-ruly a St-Bt-Pl-svoru zjišsěn muskovit. Tvoří drobné lupínky zpravidla $\mathrm{v}$ partiích bohatých biotitem a staurolitem. Jeho chemismus je uveden v tabulce 3 (vzorky 1 a 9). Zjištěn byl i v podobě sericitu (jako produkt alterace plagioklasu). Kromě ilmenitu patří k běžným akcesoriím St-Bt-Pl-ruly a St-Bt-Pl-svoru apatit$-(\mathrm{CaF})$, méně hojný je zirkon, turmalín (dravit - viz tab. 4, vzorek 9), granát s dominancí almandinové složky (tab. 4 , vzorek 2), pyrit a chalkopyrit.

\section{Diskuze}

1. O hojné přítomnosti plagioklasu v horninách bohatých grafitem v zóně Červenohorského sedla a o jeho opticky stanovené vysoké bazicitě (labradorit) se zmiňují již práce z 1. poloviny 20. století (Bederke 1935; Fabian 1936), na něž navazuje Mašek (1958). Nutno poznamenat, že biotitické plagioklasové ruly s grafitickou substancí s obdobně bazickým plagioklasem jsou známy i ze severní části vrbenské skupiny (dříve rejvízská skupina - Novotný a Štelcl 1961; Souček 1977). Z nově provedených WDX analýz je zřejmé, že v St-Bt-Pl-rule a St-Bt-Pl-svoru z okolí Koutů nad Desnou je bazicita plagioklasu v rozpětí $\mathrm{An}_{39-84}$ (8 analýz, průměr je $\mathrm{An}_{59}$, tj. labradorit), v Ch-Pl-rule $\mathrm{An}_{88-91}$ (tj. při rozhraní labradoritu a anortitu). Neobvykle vysokou bazicitu plagioklasu v horninách tohoto typu ve skupině Červenohorského sedla vysvětluje Bederke (1935) př́nosem vápníku $\mathrm{z}$ „mladého“ magmatu granodioritového složení, zatímco podle Fabiana (1936) je vápník součástí protolitu, jenž obsahoval původně kalcit. Mašek (1958) a též např. René (1970) se jednoznačně přiklání k názoru Fabiana (1936). Logickým argumentem je př́tomnost kalcitického mramoru, tvořícího čočku 
v biotitickém fylitu (Mašek 1958) či biotitickém svoru (Pouba et al. 1962) v prostoru mezi Červenohorským sedlem a Suchou horou, nebo kalcitického svoru (Mašek 1958). Vysoký obsah $\mathrm{CaO}$ ve studovaných horninách je zřejmý z tabulky 2 a z obrázku 4. Vzhledem k tomu, že jejich prakticky jediným Ca-minerálem je plagioklas (množství apatitu je nepatrné, což je zřejmé i z obsahů $\mathrm{P}_{2} \mathrm{O}_{5} \mathrm{v}$ tabulce 2), musí být bazický plagioklas podstatnou složkou většiny studovaných vzorků.

2. Protolit St-Bt-Pl-ruly a St-Bt-Pl-svoru musel být relativně bohatý nejen na $\mathrm{Ca}$, ale také na $\mathrm{Al}$ a Fe (viz tab. 2, obr. 4). Obdobně vysoké a dokonce i vyšší obsahy Al a Fe jsou známy ze staurolitických svorů v jiných úsecích vrbenské skupiny (René 2002), jde však o svory bez bazického plagioklasu a také bez grafitu (nebo s jeho jen nepatrným obsahem). René (2002) na základě chemismu staurolitových hornin silezika dochází k závěru, že jejich protolit odpovídal illiticko-kaolinickým jílům (to je velmi pravděpodobné $\mathrm{v}$ př́ípadě staurolitických svorů) nebo sedimentům s vysokým podílem montmorillonitu (jejich metamorfózou se mohly vytvořit St-Bt-Pl-ruly a St-Bt-Pl-svory). Je možné, že zdrojem materiálu sedimentů či reziduí, jejichž metamorfózou následně vznikly Ch-Pl-ruly, St-Bt-Pl-ruly a St-Bt-Pl-svory, mohly být produkty bazického vulkanismu. Kromě chemismu hornin by ve prospěch této hypotézy mohlo svědčit těsné prostorové sepětí biotitických plagioklasových rul s amfibolity a erlan-amfibolitovými stromatity v tzv. rejvízské skupině.

3. Obecně platí, že minerální asociace metamorfitu je určena povahou (složením) protolitu a podmínkami, za nichž metamorfóza probíhala. Horniny vrbenské skupiny v zóně Červenohorského sedla jsou postiženy variskou regionální metamorfózou za podmínek staurolitové zóny, výjimečně až zóny sillimanitové (napřr. René 1983; Košuličová a Štípská 2007; Schulmann et al. 2014). Nerostné složení studovaných vzorků St-Bt-Pl-rul a St-Bt-Pl-svorů staurolitové zóně zcela odpovídá. Př́ítomnost vložek Ch-Pl-ruly v tomto horninovém prostředí je patrně výsledkem retrográdních procesů v závěru variské metamorfózy, kdy mohlo dojít $\mathrm{k}$ přeměně staurolitu a biotitu na chlorit (spolu s výnosem draslíku - viz data v tab. 2 a obr. 4), provázené někdy i výrazným prokřemeněním horniny, případně vznikem křemenných žil o mocnosti řádově $\mathrm{v} \mathrm{cm}$ až několik $\mathrm{dm}$.

4. Při studiu chemismu staurolitu a vybraných akcesorií nebyly zjištěny žádné údaje, které by bylo možno považovat za anomální v rámci hornin vrbenské skupiny v prostoru zóny Červenohorského sedla. V př́padě staurolitu je to zřejmé při srovnání s údaji Novákové (2013), která zhodnotila chemismus staurolitu ze svorů z velkého počtu lokalit v sileziku. Složení granátu v St-Bt-Pl-svoru (tabulka 4, vzorek 2, odpovídající $\mathrm{Alm}_{71-72} \mathrm{Sps}_{12-13} \operatorname{Prp}_{6 \text { - }}$ ${ }_{-8} \mathrm{Grs}_{8-9}$ ) se podobá granátům ze svorů a fylitických svorů vrbenské skupiny z okolí Domašova (Fediuková 1996), obsah almandinové složky v granátech ze svorů v okolí Petrova nad Desnou je obdobný nebo i výrazně vyšší (napřr. René 1970, Košuličová 2002).

\section{Závěr}

V zóně Červenohorského sedla v okolí Koutů nad Desnou vystupuje prrímo v nadloží drakovských kvarcitů grafitická stauroliticko-biotitická plagioklasová rula, přecházející do svoru tvořeného shodnou minerální asociací. Plagioklas, jenž je podstatnou a někdy i dominantní složkou těchto hornin, má vysokou bazicitu $\left(\mathrm{An}_{39-84}\right.$, převážně jde o labradorit až bytownit, stanoveno WDX analýzami). Běžnými akcesoriemi těchto hornin jsou ilmenit a apatit-(CaF), méně hojný je zirkon, turmalín (dravit), granát (almandin), pyrit a chalkopyrit. V rulách a svorech uvedeného složení se vyskytují vložky grafitické chloriticko-plagioklasové ruly s extrémně vysokou bazicitou plagioklasu při rozhraní bytownit/anortit $\left(\mathrm{An}_{88-91}\right)$. $\mathrm{Z}$ chemického a nerostného složení těchto hornin je zřejmé, že jejich protolit musel být relativně bohatý na Fe, $\mathrm{Al}$ a také Ca. Lze předpokládat, že šlo o jílové horniny, jejichž vznik byl možná spojen se zvětráváním produktů bazického vulkanismu.

\section{Poděkování}

Autor děkuje editorům a recenzentu za kritické pročtení rukopisu a pripomínky, které vedly k jeho zkvalitnèní. 


\section{Literatura}

Bederke, E. (1935): Die Regionalmetamorphose im Altvatergebirge. - Geologische Rundschau, 26, 1-2, 109-124.

Budil, P. - Štěpánek, P. - Adamovič, J. - Coubal, M. - Chlupáč, I. - Opletal, M. - Valečka, J. (1999): Examplex of important geological localities in the Sudetes (Czech Republic). - Polish Geological Institute Special Papers, 2, 27-32.

Fabian, H.-J. (1936): Die Metamorphose devonischer Phyllite im Altvatergebirge. - Chemie der Erde, 10, 3, 343-408.

Fediuková, E. (1996): Železem bohaté granáty z devonských kvarcitů a svorů při jz. okraji jesenického amfibolitového masívu v okolí Bělé. - Geologické výzkumy na Moravě a ve Slezsku v roce 1995, 3, 81-82.

Feenstra, A. - Ockenga, E. - Rhede, D. - Wiedenbeck, M. (2003): Li-rich zincostaurolite and its decompression-related breakdown products in a diaspore-bearing metabauxite from East Samos (Greece): An EMP and SIMS study. - American Mineralogist, 88, 789-805.

Fojt, B. - Gregerová, M. (1999): Stručný petrografický popis hornin vrtu J-1 a J-2 v území plánovaného tunelu mezi Kouty nad Desnou a Bělou pod Pradědem. - Geologické výzkumy na Moravě a ve Slezsku v roce 1998, 6, 109-112.

Cháb, J. - Opletal, M. (1984): Př́krovová stavba východního okraje skupiny Červenohorského sedla v Hrubém Jeseníku. - Věstník Ústředního ústavu geologického, 59, 1, 1-10.

Košuličová, M. (2002): Svory v okolí Petrova nad Desnou a Ramzové. MS. Diplomová práce. PřF UP Olomouc.

Košuličová, M. - Štípská, P. (2007): Variations in the transient prograde geothermal gradient from chloritoid-staurolite equilibria: a case study from the Barrovian and Buchan-type domains in the Bohemian Massif. - Journal of Metamorphic Geology, 25, 19-36.

Kováčik, M. - Opletal, M. - Pecina, V. - Žáček, V. (2010): Pumpellyit - minerál závěrečné metamorfní fáze v bytownitové rule vrbenské skupiny a v amfibolitu jesenického masivu (silezikum). - Geologické výzkumy na Moravě a ve Slezsku, 17, 1-2, 151-155.

Mašek, J. (1958): Geologicko-petrografické poměry v severovýchodním okolí Koutů v Hrubém Jeseníku. - Př́rodovědný sborník Ostravského kraje, 19, 2, 279-306.

Melka, K. (1965): Návrh na klasifikaci chloritových minerálů. - Věstník Ústředního ústavu geologického, 40, 23 -27.

Nováková, Z. (2013): Chemizmus staurolitu svorů silezika. MS. Bakalářská práce. PřF UP Olomouc.

Novotný, M. - Štelcl, J. (1961): Petrografie severovýchodní části Hrubého Jeseníku. - Folia Facultatis Scientiarum Naturalium Universitatis Purkynianae Brunensis, Geologia, 2, 3-124.

Opletal, M. - Sekyra, J. - Novák, M. (1997): Geologická mapa ČR. List 14-24 Bělá pod Pradědem. Český geologický ústav, Praha.

Pouba, Z. - Dvořák, J. - Kužvart, M. - Musilová, L. - Prosová, M. - Röhlich, P. - Skácel, J. - Unzeitig, M. (1962): Vysvětlivky k přehledné geologické mapě ČSSR 1:200 000, M-33-XVIII Jeseník. Ústřední ústav geologický Praha.

René, M. (1970): Petrologie série Červenohorského sedla. MS. Rigorózní práce. PřF UK Praha.

René, M. (1983): Geochemie a petrologie metapelitů obalových sérií jádra desenské klenby. - Časopis pro mineralogii a geologii, $28,3,277-286$.

René, M. (2002): Staurolitové horniny Hrubého Jeseníku. - Sborník „Mineralogie Českého masivu a Západních Karpat“, 70-74. UP Olomouc.

Schulmann, K. - Oliot, E. - Košuličová, M. - Montigny, R. - Štípská, P. (2014): Variscan thermal overprints exemplified by U-Th$-\mathrm{Pb}$ monazite and K-Ar muscovite and biotite dating at the eastern margin of the Bohemian Massif (East Sudetes, Czech Republic). - Journal of Geosciences, 59, 389-413.

Souček, J. (1977): Dark biotite-plagioclase gneisses of the Rejvíz series. - Acta Universitatis Carolinae, Geologica, 1977, 1-2, $151-167$.

Zimák, J. - Dalajková, K. - Donocik, R. - Krist, P. - Reif, D. - Štelcl, J. - Kopecká, L. (2016): Využitelnost terénních rentgenfluorescenčních analyzátorů ke stanovení chemismu cementářských surovin - na př́kladu velkolomu Mokrá. - Zprávy o geologických výzkumech, 49, 79-82. 